\title{
COMPETENCE AS AN OBJECT CATHEGORY AND ACHIEVING EDUCATION RESULTS COMPLEXITY
}

\author{
Jitka PLISCHKE - Jiř́ KROPÁC̆
}

\begin{abstract}
The article tends to questions of complexity (integrity) of technical subjects instruction. This complexity can be viewed in horizontal direction, i. e. as complexity of contents substitutability, as well as in vertical direction as a connection of theoretical cognition with its practical use for pupil's creative activities when mastering the learning contents. Formulating object aims in form of competences is considered by the authors to be appropriate for viewing the instruction complexity and its results.
\end{abstract}

Key words: technical subjects, competence, competence factors, complexity of instruction results.

\section{KOMPETENCE JAKO CÍLOVÁ KATEGORIE A DOSAHOVÁNÍ KOMPLEXNOSTI VÝSLEDKŮ VÝUKY}

Resumé: Stat' je směřována k otázkám komplexnosti (úplnosti) výuky technických předmětů. Tato komplexnost může být posuzována jak ve směru horizontálním, tedy jako komplexnost zastoupení obsahu, tak ve směru vertikálním jako spojení teoretického poznání s jeho praktickým uplatněním v tvořivých činnostech žáka při osvojování obsahu. Vyjádření cílových záměrů formou kompetencí autoři považují za vhodné pro posouzení komplexnosti výuky a jejích výsledků.

Klićová slova: technické předměty, kompetence, složky kompetence, komplexnost výsledků výuky.

\section{1 Úvod}

Slovem komplexnost vyjadřujeme v názvu stati úplnost, $v$ daném př́ípadě vlastnost(i) výuky svými vzdělávacími výsledky naplit „požadované záměry“ v odpovídajícím rozsahu a hloubce. Řada statí již dokumentovala dř́ivější zúžené a tedy nekomplexní pojetí výuky technických předmětů na ZŠ, jež namnoze přetrvává dosud. V této stati se chceme zabývat vybranými souvislostmi využití pojmu kompetence jako cílové kategorie $\mathrm{v}$ technických předmětech a dosahováním komplexnosti výuky technických předmětů.

\section{Koncipování obsahu a očekávané výsledky výuky v obecněji zaměřených technických předmětech \\ V technických predmětech je třeba pokládat} otázku, kdy je potřebné zaměření pozornosti na obsah odrážející okruhy životní praxe důležité pro budoucí život žáka, a zda vůbec, v jakém rozsahu a kdy je vhodné systematické zařazení vybraných oblastí teorie, jež je ve své podstatě obecná. Jinak řečeno - kdy má obsah vzdělávání odrážet ze „trrí světů Karla Poppera“ svět 1 (svět fyzického prostředí, techniky, př́rody ...) a kdy svět 3 (svět výtvorů lidského ducha, vědy, kultury, umění ...), podrobněji (1).
Pro první uvedené (svět 1), kdy okruhy obsahu jsou do značné míry zvoleny na základě utilitární racionality (označení použité J. Skalkovou), tedy zvládnutí určitých „oblastí života“, je typické právě výrazné směřování vzdělávání k vytváření kompetencí. Jejich použití jako prostředku vyjádření výukových záměrů (cílové kategorie) je logické. To významně platí pro technické předměty, zaměřené na zvládnutí technických činností (činností spojených s užitím techniky), přestože soustavné poučení o „Zvolených úsecích" technické teorie je nezbytné a v odborném vzdělávání na vyšších stupních škol je dominantní (i zde však je výrazně zastoupeno hledisko kompetentního využití osvojeného).

Můžeme se setkat s rozpaky nad snížením významu žákova systematického poznávání, poprrípadě snížením významu kultivační funkce vzdělávání. To spočívá především v poznání výtvorů lidského ducha, kultury, vědy, umění. Tato výčitka nemůže platit u technických předmětů, u nichž prioritní zaměření na svět 1 patří k podstatě. $\mathrm{O}$ vzdělávacích a výchovných možnostech, které obsah výuky o technice nese, jsme pojednali jinde (2), (3).

Teoretické zdůvodnění uvedených př́istupů k výběru a usporáání obsahu výuky provedl S. Štech (4). Popisuje dva „kódy“, v nichž je 
učivo prezentováno. Kód seriální znamená, že učivo je odvíjeno od oborových poznatků „spíš teoretického rázu“, odkud je odvíjena i snaha o komplexnost. Potom ,základní charakteristikou je separace, oddělování, rozlišování a třídění kategorií jako jednotek majících vztahy k jiným jednotkám. Poznatky jsou v tomto kódu hierarchicky organizované ...", uvádí S. Štech

(4, s.109). Dále upřesňuje, že ,účinnost pohybu v seriálním kódu významů, oddělených od konkrétních kontextů a situací, spočívá ve stanovování vztahů mezi abstraktními významy.“ Zřejmě tedy odráží svět 3 Karla Poppera. Podle našeho názoru je tento kód adekvátní technickému teoretickému, průřezovému obsahu a prŕislušné výuce (technická mechanika, teoretické základy elektrotechniky, technická grafika, nauka o materiálech atp.).

Druhý typ kódu označuje S. Štech jako integrovaný. Spíše než o pojmech jako myšlené formě odrazu reality $\mathrm{v}$ nich hovoří o tématech, která mohou překračovat hranice jednotlivých vyučovacích předmětů (4, s.110). Dále citujme: „Strategie vzdělávání v tomto kódu jsou lokální, tj. specifické, inspirované domácím či vrstevnickým mimoškolním prostředím. Poznatky nejsou hierarchicky uspořádané, ale segmentované. Stojí vedle sebe, nezávisle na sobě, a jsou osvojovány v konkrétním kontextu, na kterém závisí. Proto jsou vyučovací postupy i učivo extenzivní a průřezové - jsou konstruovány tak, aby umožnily projít zkušeností s co největším počtem situací, kontextů, osob, míst atd." (4, s.110).

Ke kódu nazvanému integrovaný lze podle našeho tématu zařadit vybrané oblasti obsahu výuky technických předmětů, které představují témata významná pro budoucí činnost žáků s technikou, jsou pro ně přitažlivá a mají potenci rozvíjet osobnost žáka; další kriteria výběru či požadavky na obsah technických předmětů jsme uvedli jinde (5). Tato témata jsou do určité míry izolovaná, nastupuje tedy otázka integrace poznání žáka a otázka komplexnosti či úplnosti výuky; ta je předmětem této stati. Jak k ní mohou přispět kompetence jako cílová kategorie vzdělávání?

\section{Kompetence, jejich složky ...}

Pedagogický pojem kompetence byl původně využíván ve sféře vzdělávání odborného (6), převzat byl i do vzdělávání všeobecného, s měnícími se náhledy na jeho úlohy. Dosud ovšem chybí jeho všeobecně přijímané vyjádření či formulace. Toto konstatování je opakováno ve statích čísla časopisu Pedagogika (7), v němž je kompetencím a jejich významu v RVP věnována pozornost předními českými pedagogy. Podle nás platí i dnes, přestože je řada nových publikací směřujících k rozpracování pojmu kompetence, např̀. (8).

V technickém vzdělávání se kompetencí rozumí ucelené zvládnutí smysluplné činnosti, nelze tedy považovat napřr. formulaci uvozenou slovy ,žák je způsobilý vyjmenovat ....", za formulaci cíle, který vystihuje kompetenci. Podle D. Nezvalové (9, s. 10) jsou kompetence „obvykle definovány jako soubory integrovaných znalostí, dovedností a postojů. [...] často značí určitou schopnost či potenciál účinně jednat v daném kontextu“. V charakteristice D. Nezvalové jde o rozčlenění pojmu kompetence na složky v ČR obvyklé, tedy na znalosti, dovednosti a postoje, v zahraničí se setkáváme i s jiným členěním.

V publikaci (10) jsme uvedli pojmy, s nimiž jsme se v literatuře setkali ve smyslu složky kompetence. Jsou to především: znalosti, dovednosti duševní i motorické, postoje, schopnost účinně jednat, chování, poznávání, prožívání, dimenze obsahové, metodicko strategické, sociální (komunikativní, mentálně afektivní), motivace, sociální zralost, odbornost, subjektivní svět, společenský svět, učení, metody a způsoby činnosti, komunikace. Tento námi provedený výběr ukazuje značnou multidimenzionálnost a kompozitní charakter pojmu kompetence, složky jej tvořící (napřr. znalosti) mohou představovat faktory vedoucí také kintegraci kompetencí, zdánlivě nesouvisejících.

\section{... a možnosti dosahování komplexnosti výuky v technických předmětech}

Při koncipování obsahu výuky technických předmětů jsou vybrána témata, prezentovaná v integrovaném kódu (integrovaná k určitému významnému obsahovému celku, ne mezi těmito celky), zvládnutí těchto témat v technických předmětech znamená především odpovídající zvládnutí kompetencí. Tato témata však mohou být propojena výukou průřezových, teoretických, obecnějších obsahových celků určených k zajištění nezbytných znalostí pro uvědomělé osvojení kompetencí (tedy znalostí tvořících složku kompetencí). Využití pojmu kompetence (zde při respektování zásady uvědomělosti) je nástrojem dosahování komplexnosti výuky a jejích výsledků tehdy, jsou-li kompetence chápány komplexně a rozbaleny na složky (11); 
$\mathrm{v}$ rámci složek může probíhat integrace a být dosahována úplnost. Zjednodušeně - chápejme dosahované kompetence dostatečně komplexně, ale uvědomme si, z čeho se skládají a co je potřeba (jaké složky a co $\mathrm{v}$ nich) $\mathrm{k}$ jejich dobrému osvojení. Nemusí jít jen o znalosti, jako ve výše uvedeném príkladu, ale i o jiné vhodné složky pojmu kompetence.

V tomto smyslu může vhodný způsob práce $\mathrm{s}$ kompetencemi sloužit $\mathrm{k}$ ucelenosti i integraci ve smyslu horizontálním. Zde využíváme terminologie Z. Kubíčka (12, s. 67-68), který $\mathrm{v}$ návaznosti na další autory rozlišoval při vzdělávání integraci:

- horizontální - vytváření vazeb mezi vyučovacími předměty, jejich obsahem a postupy (mezipředmětové vztahy),

- vertikální - propojování teoretických poznatků $\mathrm{s}$ praktickými činnostmi žáků, propojování učiva a procesu výuky s reálným světem, praktickými problémy a situacemi, tedy v úzké souvislosti myšlení, znalostí a schopnosti konat.

Při horizontální integraci jde tedy o ucelenost ve smyslu návaznosti obsahu, analogicky nám jde také o úplnost obsahu ve smyslu jeho zastoupení potřebného $\mathrm{k}$ tomu, aby dané technické předměty plnily očekávané poslání.

Povšimněme si dále myšlenky vertikální integrace, $i \mathrm{v}$ tomto směru je totiž potřeba obsah vzdělávání vytvářet ucelený, ale také úplný. Technické předměty vyučované na ZŠ v minulosti nebyly ani $\mathrm{z}$ tehdejšího hlediska úplné jak ve směru horizontálním, tak vertikálním. Vhorizontálním směru dlouho v podstatě absentovala nejen výpočetní (digitální) technika, nebyly dostatečně zastoupeny vztahy techniky a vedení domácnosti i techniky a práce ve volném čase, např. zájmového charakteru. Výuka byla zacílena „př́lišs výrobně“, na osvojování řemeslných dovedností, ale ani prováděné ruční technologie nebyly prioritně zacíleny na činnosti v domácnosti (údržba), ale především na činnosti obvyklé spíš při výrobě.

Ve smyslu vertikálním nesl dř́vější systém z hlediska komplexnosti rovněž nedostatky. Nelze popř́it dřivější vysoké zastoupení samostatné a praktické činnosti žáků v technických předmětech. Školy disponovaly více či méně dobře vybavenými výukovými prostorami a byly podporovány materiálovými středisky, pro tento účel zřízenými tehdejšími školskými orgány. Nedostatek spočíval $\mathrm{v}$ nedostatečném rozvíjení technických znalostí žáků a $v$ nedostatečné opoře o ně při rozvíjení technických dovedností žáků (pojem kompetence nebyl dříve využíván). Nebyla dostatečně uplatňována ani aplikace znalostí žáků z jiných vyučovacích předmětů. Nevyužity zůstávaly mnohé výchovné potence, blíže viz (2). Při tehdejším nevyužíání pojmu kompetence, kdy osvojení činností žákem bylo popisováno pouze pojmem dovednosti, bylo toto jednou $\mathrm{z}$ prričin tehdejší neúplnosti či nekomplexnosti výuky technických předmětů.

\section{Závěr}

Úvahy o úplnosti i ucelenosti výuky jsou $\mathrm{v}$ dnešní době významné vzhledem $\mathrm{k}$ pravomoci škol ovlivňovat zastoupení a uspořádání obsahu i způsoby realizace procesů jeho osvojování žáky (tvorba ŠVP). Dnes jako požadavek na zařazení do vzdělávání vystupuje pro technické předměty nejen digitální technika, ale celá řada oblastí dalších. Potom však vzniká otázka, jak některé tyto „soudobé požadavky“ ve výuce uplatnit tak, aby vedly $\mathrm{k}$ aktivní tvořivé činnosti a ke kompetencím, nejen $\mathrm{k}$ informovanosti. Jak tedy např. učit nanotechnologie, jichž je dnes všude plno, nebo je neučit? Jen spolupráce školy a př́slušného oboru může vést $\mathrm{k}$ řešení těchto otázek.

Koncipování obsahu tak, aby jeho osvojení směřovalo ke kompetencím, může být $\mathrm{z}$ tohoto hlediska užitečné. Formulace kompetencí umožňuje posoudit, zda jde o zaměření výuky na činnosti pro žáka skutečně potřebné či užitečné a také rozvíjející. Užitek (význam) je nesporně podstatným argumentem pro výuku technických predmětů; posoudit užitečnost i úplnost lze výhodně právě u "celkư“ vyjádřených formou kompetencí žáka. Je ovšem třeba rozčlenit kompetence na jejich složky; ty musí být chápány ve vztahu ke kompetencím, jako předpoklad jejich dobrého osvojení, ale současně mohou vytvářet vazby mezi různými oblastmi obsahu.

\section{Literatura:}

[1] HEJNÝ, M. a KUŘINA, F. Tři světy Karla Poppera a vzdělávací proces. Pedagogika, 2000, roč. 50, č. 1, s. 38-50. ISSN 3330-3815.

[2] KROPÁČ, J. a CHRÁSKA, M. Výchova $v$ obecně technických predmětech. Olomouc : Univerzita Palackého, Pedagogická fakulta, 2004. ISBN 80-244-0897-X.

[3] KROPÁČ, J. a KROPÁČOVÁ, J. Didaktická transformace pro technické predméty. Olomouc : Univerzita Palackého, Pedagogická fakulta, 2006. ISBN 80-244-1431-7.

[4] ŠTECH, S. Zřetel k učivu a problém dvou 
modelů kurikula. Pedagogika, 2009, roč. 59, č. 2, s. 105-115. ISSN 0031-3815.

[5] KROPÁČ, J. K vymezení požadavků na obsah výuky v obecně technických předmětech. In Trendy technického vzdělávání 2001 (dodatky). Olomouc: Univerzita Palackého, 2001, s. 19 - 22. ISBN 80-244-0375-7.

[6] JUNG, E. Die Bedeutung des berufspädagogischen Kompetenzmodells für die aktuelle Kompetenzdiskussion und Gestaltung von Curricula zur arbeitsorientierten Bildung. Unterricht - Arbeit + Technik, 2005, Jahrgang 7, Heft 26, S. 53-56. ISSN 1438-8987.

[7] Pedagogika, 2005, roč. 55, č. 1, s. 4 - 19. ISSN 3330-3815.

[8] VETEŠKA, J. a TURECKIOVÁ, M. Vzdélávání a rozvoj podle kompetenci: Kompetence $v$ andragogice, pedagogice a ř́zení. Praha: Univerzita Jana Amose Komenského, 2008. ISBN 978-80-86723-54-9.

[9] NEZVALOVÁ, D. Rámcový a školní vzdělávaci program [online]. - [cit. 2011-03-17]. Dostupný z WWW:

$<$ http://esfmoduly.upol.cz/texty.html $>$.

[10] KROPÁČ, J. st. a KROPÁC̆, J. ml. Koncepce obecně technických předmětů a využití kompetencí jako cílové kategorie. In XXII.
DIDMATTECH 2009. Trnava-Komárno: Trnava University, J. Selye University, 2010, s. 312-316. ISBN 978-80-8122-006-7. EAN 9788081220067. [11] HAUSENBLAS, O. Modelové rozpracování kličových kompetencí [online]. - [cit. 2011-0318]. Dostupný z $\quad$ WWW: http://clanky.rvp.cz/clanek/o/z/435/MODELOVE -ROZPRACOVANI-KLICOVYCH-

KOMPETENCI.html/

[12] KROPÁČ, J., KUBÍČEK, Z., CHRÁSKA, M. a HAVELKA, M. Didaktika technických predmétů: vybrané kapitoly. Olomouc: Univerzita Palackého, 2004.ISBN 80-244-08481.

PhDr. Jitka Plischke, Ph.D.

Doc. PaedDr. Jiří Kropáč, CSc.

Ústav pedagogiky a sociálních studií

Pedagogická fakulta UP

Žižkovo nám. č. 5

771 40, Olomouc, ČR

Tel: +420 585635173

E-mail: jitka.plischke@upol.cz

Www pracoviště: http://www.upss.cz/ 